\title{
AINDA UM ASSASSINATO BÁRBARO IMPUNE: violência, impunidade e conflito agrário no sul de Pernambuco (1917-1919)
}

\author{
Vilmar Antônio Carvalho*
}

\begin{abstract}
RESUMO: Este artigo investiga o conflito que envolveu duas famílias de proprietários rurais da cidade de Palmares. Os clãs Peregrino e Marques, adversários pelo controle e posse da fazenda Cachoeira Bela, localizada no distrito de Maraial, região canavieira do estado de Pernambuco. A investigação considera as práticas e representações de violência e impunidade contextualizadas em diversas notas publicadas na capital Recife, algumas delas assinadas pelos patriarcas envolvidos, seus parentes ou correligionários. Nesta estratégia de pesquisa destacam-se, também, o confronto entre o repertório de ideias sobre civilidade e modernidade, à época bastante difundido nos jornais, e o fragrante contraste com as notícias publicadas sobre as violências cometidas na região canavieira. Um histórico de disputas de terra que terminavam envolvidas com o poder local e as questões políticas do coronelismo.
\end{abstract}

PALAVRAS-CHAVE: Modernidade; Coronelismo; Oligarquias; Pernambuco.

\section{Still a barbarian murder unpunished: violence, impunity and agrarian conflict in the south of Pernambuco (1917-1919)}

\begin{abstract}
This article investigates the conflict involving two families of rural owners in the city of Palmares. The Peregrino and Marques clans, opponents for control and possession of the Cachoeira Bela farm, located in the Maraial District, sugarcane region of Pernambuco, Brazil. The research considers practices and representations of violence and impunity contextualized by the notes published in the capital Recife. Some of them signed by the patriarchs involved, their relatives or supporters. This research strategy highlights the confrontation between the ideas about civility and modernity that were widely published in the newspapers of the time - and the contrast with the published news about the violence committed in the sugarcane region. A history of land disputes involving local power and the political issues of the Colonels system.
\end{abstract}

KEYWORDS: Modernity; Colonels; Oligarchies; Pernambuco.

\section{Aunque un asesinato bárbaro impune: violencia, impunidad y conflicto agrario en el sur de Pernambuco (1917-1919)}

RESUMEN: Este artículo investiga el conflicto que involucró a dos familias de terratenientes de la ciudad de Palmares. Los clanes Peregrino y Marques, adversarios por el control y posesión de la hacienda Cachoeira Bela, districto de Maraial, ubicada em la región cañera del la provincia de Pernambuco. La investigación considera las prácticas y representaciones de violencia e impunidad contextualizadas en diversas notas publicadas en la capital Recife, algunas de ellas firmadas por los patriarcas inclusos, sus parientes o correligionarios. Se destaca, en esta estrategia de investigación, el enfrentamiento entre el repertorio de las ideas de civililidad y modernidad, en la época bastante difundidas en los periodicos, y el fragante contraste con las noticias publicadas sobre las violencias cometidas en la región cañera. Un histórico de disputas por la tierra que terminaban involucradas em las cuestiones del poder local y las políticas del coronelismo.

PALABRAS CLAVE: Modernidad; Coronelismo; Oligarquías; Pernambuco.

\footnotetext{
* Mestre em História pela Universidade Federal de Pernambuco. Atualmente é professor de História Moderna e Contemporânea na Faculdade de Formação de Professores da Mata Sul (FAMASUL). Contato: BR 101, km 117, Palmares-PE, Brasil. E-mail: vilmarcarvalho4@ hotmail.com.
} 


\section{Introdução}

Ainda um assassinato bárbaro impune... Esta nota publicada no jornal A Província ${ }^{1}$, em 1917, desencadeou um conjunto de notícias sobre a "onda de sangue" que envolvia Palmares e os distritos de Catende e Maraial ${ }^{2}$. A nota registrava o ataque dos Marques à família Peregrino. Um episódio violento motivado pela disputa de terras pertencentes ao engenho Cachoeira Bela ou Meia Água, evento que resultou na morte de um jovem membro dos Peregrino.

Dois anos depois, no início de 1919, entre trâmites judiciais e insultos na imprensa, a família Peregrino revidou o assassinato do parente, deixando muitos feridos e três mortos entre os Marques. O revide foi chamado, pela imprensa, "A hecatombe do engenho Gigante" ${ }^{3}$. Uma comparação com os acontecimentos transcorridos em Garanhuns, envolvendo as famílias Ivo, Miranda e Jardim4. Os jornais narravam os dois episódios e cobravam providências ao governador Manoel Borba, para que botasse fim à "desordem" reinante e pacificasse as famílias do interior do estado.

A repercussão de tais conflitos evidenciava um conjunto de práticas e representações sociais relacionadas à violência e à impunidade. Práticas mobilizadas pelos mandões do interior, para preservar o poder e os interesses políticos que marcavam as relações paternalistas existentes entre as oligarquias agrárias e o poder central, conforme analisa Bursztyn $^{5}$, quando se refere ao esquema de legitimação dos coronéis:

Em primeiro lugar, porque apresenta-se como um mecanismo eficaz na consolidação das relações de dependência que subordinam os trabalhadores aos caciques locais, tanto ao nível econômico (via endividamentos eternos resultantes do sistema de "adiantamentos" que historicamente funcionam como financiamentos à pequena produção) como social (via relações de compadrio, que unem, de forma subordinada, minifundiários a latifundiários). Em segundo lugar, e como decorrência lógica, essa dependência irá refletir-se no nível político, onde os poderosos locais sempre lograram impor sua vontade, desde a época colonial - quando possuíam prerrogativas de justiça e militar - passando pelo império - quando eram nomeados coronéis da Guarda Nacional -, até o período republicano - quando a forma de subordinação do trabalho ao capital no campo permite a emergência do voto de cabresto e dos currais eleitorais.

Deste modo, as notas de jornal investigadas, mediadas pelas abordagens do coronelismo, suas práticas e representações, assinalam as discussões a respeito do chamado sistema político da Primeira República brasileira ${ }^{6}$. Sobre o fenômeno político do coronelismo, José Murilo de Carvalho, por sua vez, afirma que existem estudos numerosos e fluentes, mas, ainda, por se aprofundar quando o registro pretendido é o poder local ${ }^{7}$. Uma abordagem que requer a aplicação dos conceitos de mandonismo, coronelismo, clientelismo e a 
contextualização do ambiente político onde, por exemplo, se enredaram inúmeros conflitos envolvendo os mandões do interior do país.

Em Pernambuco, a Hecatombe de Vitória de Santo Antão ${ }^{8}$, gerada pelas questões políticas acirradas entre liberais "Democratas" e "Leões"9; anos depois, os conflitos armados entre os partidários rosistas e dantistas, que resultaram dos confrontos da "sucessão pernambucana" de Rosa e Silva e Dantas Barreto ${ }^{10}$; a Hecatombe de Garanhuns e tantos outros inúmeros incidentes, patrocinados por chefes políticos municipais, proprietários rurais e seus familiares, compõem uma história local de rixas pessoais, eleitorais, disputas de terra, crimes de encomenda, vingança ou mesmo latrocínio. Acontecimentos que explicam a amplitude do mandonismo e de como este foi rearticulado pelos coronéis e sua rede clientelista, principalmente nas primeiras décadas do século passado.

Neste caso de Palmares, podemos verificar um quadro de conflitos e violência que denuncia as "estruturas oligárquicas personalizadas de poder"11 advindas do Império e enraizadas na Primeira República. As rotinas da política tradicional e a forma como os coronéis submetiam as populações ao julgo das armas, processos violentos e posterior tentativa de impunidade. Processos que demonstram a tese de que coronelismo, mandonismo e clientelismo, ainda que fenômenos distintos, conforme acentua o balanço historiográfico sobre a Primeira República, realizado por Ângela de Castro Gomes e Marieta de Morais Ferreira $^{12}$, formavam uma rede complexa de relações entre o poder político e os chefes locais:

O coronelismo não era uma mera sobrevivência do poder privado, cuja hipertrofia constitui fenômeno típico da história colonial e imperial brasileiras, mas sim um compromisso, uma troca proveitosa entre o poder político progressivamente fortalecido, e a decadente influência dos chefes locais, notadamente os donos de terra. Trata-se, portanto, de uma rede complexa de relações em que os remanescentes do poder privado são alimentados pelo poder público em função de suas necessidade eleitorais de controle do votos do interior. Dessa maneira, o coronelismo não deve ser confundido com algumas de suas características secundárias, como mandonismo e clientelismo.

Deste enfoque historiográfico bastante amplo, apoiado nos estudos pioneiros de Vítor Nunes Leal, consideramos que as notas de Palmares podem ganhar relevo. É possível analisar, a partir delas, práticas e representações sociais mobilizadas pela oligarquia açucareira. Como igualmente, vislumbrar a autoimagem, as facções e redes de relacionamento público e privado acionadas pelos coronéis.

A fonte pesquisada é uma correspondência de mais de trinta notas enviadas de Palmares e Maraial, publicadas entre 1906 e 1919 nos jornais de Recife. Elas apontam a tradição de mando vinda dos tempos da Guarda Nacional ${ }^{13}$; a manutenção de poder e privilégios alçados pela Constituição de 1891 e as lógicas paternalistas suscitadas pela 
Política dos Governadores ${ }^{14}$. Ali, também, a tentativa de articular tradição e modernidade. São evidentes da mesma forma os obstáculos e revezes que o coronelismo sofria com o crescente processo de urbanização, avanço das relações econômicas capitalistas e transformações culturais irradiadas pelas inovações e novidades da sociedade moderna. Um conjunto de tensões que explicam porque o coronelismo nunca se constituiu absoluto, capaz de submeter o local às condições manifestas de seus interesses, mandos e desmandos, além do fato de se apoiar naquele equilíbrio político exógeno, irradiado de cima pelos governadores e, mais acima, pelo poder central ${ }^{15}$. Outro aspecto é o fato daquela geração de coronéis defender a modernização do país, muito mais apoiados numa retórica extraída do repertório modernista da chamada Geração $1870^{16}$. Na prática, nenhuma efetiva transformação nas relações de poder e mando locais.

A violência praticada pelos proprietários de terra, mesmo com a escravidão abolida, continuava pautando a vida do vasto interior do país. Os troncos, surras e capatazes continuavam intimidando a população rural $^{17}$. Os civilizados senhores dos grandes centros urbanos, muitas vezes, se transformavam nos mandões brutos dos grotões do interior, apesar do pertencimento à cepa dos "bons", "de bem", civilizados e modernos. Os coronéis procuravam manter intactos os privilégios e os interesses que sustentavam o poder fundiário, familiar, eleitoral e miliciano.

O coronelismo e a configuração oligárquica da Primeira República, podemos afirmar, correspondiam à perspectiva de reprodução do poder local autoritário e hierárquico. Entretanto, os posicionamentos da oligarquia agrária, diante do incipiente estado nacional republicano e presidencialista, as manobras para ocupação de cargos públicos, o controle eleitoral e miliciano da população local, terminavam refletidos em agrupamentos de interesse diversos, movimentados pelo parentesco, filiação a partidos políticos e posse das chefias de polícia local. Objetivos que colocavam os coronéis e seus familiares no protagonismo de constantes conflitos armados, autojustificados em defesa da propriedade, honra, elevada moral e bons costumes como poderemos ver adiante.

Embora as famílias Peregrino e Marques não representassem maior prestígio político e econômico no sul de Pernambuco, e seus patriarcas fossem apenas reconhecidos capitão Peregrino Leite e tenente Antônio Marques da Costa, agricultores membros menores da Guarda Nacional, a "hecatombe do engenho Gigante" chama atenção pelo fato do desfecho das violências praticadas e a tentativa de buscar proteção e impunidade, ao procurar os respectivos padrinhos políticos estaduais. Um conjunto de manobras que se desenrolavam ao longo do conturbado governo Manoel Borba (1915-1919), responsável pelo chamamento às 
armas: "quem tiver o que perder e quiser viver em paz, vote no Governo" ${ }^{18}$. Uma convocação imposta à fraturada política pernambucana da época, onde fracionados grupos rosistas, dantistas e borbistas se recortavam na tentativa de submeter a política interiorana sob controle.

Por tudo apresentado acima, finalmente, perguntar: por que procurar história esquecida, envolvendo memórias deixadas em jornal? Por que revisitar tema recorrente, por tratar coronelismo, mandonismo e clientelismo? Por que voltar à modernidade sem mudança de Pernambuco? Talvez porque houve, na esteira daquelas transformações, muitos choques entre interesses urbanos e rurais, representações de honra e civilidade, como também, entre a ordem pública estabelecida pela política dos coronéis e o fracionamento de suas aspirações oligárquicas, considerando que - como sistema de dominação - o coronelismo impusera uma conflituosa deferência de lugares e correspondentes sociabilidades. Um conjunto de relações hierarquizadas, sempre na tentativa excludente de levar mais longe a dominação sobre a vida local.

Eis, portanto, uma estratégia de pesquisa debruçada sobre notas de jornal, outrora encomendadas para manchar a imagem pública de opositores. Notas recheadas de embustes grosseiros e irônicos, além de se impor enquanto lugar apropriado para "solicitar" providências às autoridades estaduais. Ou melhor, insinuar a impunidade e o tráfico de influência comum aos coronéis e sua rede de apadrinhados. Uns textos de jornal que serão, constrangidos à reflexão que faz dialogar práticas e representações, sobre aquele tempo marcado pela crise das tradicionais oligarquias rurais de Pernambuco. Situação que abre a possibilidade de melhor entender porque a violência transformou-se no leit motive daquele surto de processo civilizador, pois, em meio as notas sobre modernidade, chama muita atenção os crimes sangrentos praticados pelas famílias Peregrino e Marques, sempre em nome da honra, justiça e civilidade.

\section{Cachoeira Bela ou Meia Água? Processo civilizador e violência}

A história de sucessivas vinganças, entre as famílias Marques e Peregrino, começa com a disputa de terras e se emaranha com questões políticas do município de Palmares. Um pano de fundo oligárquico, evidenciado pelos trilhos da ferrovia e demais instituições que pretendiam civilizar a população interiorana, envolvendo as chamadas "famílias de bem". Um conjunto de sociabilidades modernas que procuravam difundir valores civilizados, ainda que testados em espaços de forte tradição agrária, patriarcalismo e analfabetismo generalizado. 
Uma faceta daquele processo civilizador, desencadeado pela difusão de valores da cultura letrada, cujo discurso se encontrava favorecido pelo desenvolvimento da vida urbana nas primeiras décadas do século passado. Um contexto de modernização conservadora, onde o uso violento de armas e atentados denunciava permanências de antigas relações e rotinas de poder do latifúndio canavieiro colonial.

Os protagonistas daquela modernização conservadora eram proprietários de terra que passavam administrar engenhos e fazendas, morando em sobrados edificados na cidade. Uns homens violentos que cultuavam a autoimagem de "cidadãos ativos", urbanos, instruídos e civilizados. No entanto, a história de suas vidas e famílias resultavam, quase sempre, na face de violência que marcou a rede autoritária, clientelista e miliciana do coronelismo. Um cenário que demonstrava as agruras de "civilizar por cima"19 e as intrigas cotidianas existentes entre as aspirações de mando econômico, político e social. Práticas de um tempo recentemente escravocrata, tradicionalmente autoritário, em confronto com aquele projeto de modernização da região canavieira, astutamente envolvido numa opção de poder político que respondesse à crise da lavoura canavieira ${ }^{20}$ da época e, não obstante, mantivesse a máxima das práticas de poder do latifúndio bem conservadas, pois, quanto maior a posse de terras, o prestígio político e a decorrente rede de favores, entre elas a moeda valiosa da impunidade. $\mathrm{O}$ ocultamento dos crimes praticados pelos coronéis, seus homens de confiança e cangaceiros.

Um modo de vida que os tornava noticiados pelos jornais, principalmente quando recebiam, às portas dos honrados sobrados da família, autoridades graúdas e importantes. Uma dúzia de casas que embelezavam a cidade e as sedes de seus distritos, engenhos e usinas. Um lugar reconhecido enquanto importante "empório comercial do interior", cortado por um "progressista caminho de ferro". Sobre Palmares, costumava-se dizer à imprensa: uma terra de letrados laboriosos ${ }^{21}$, diariamente ligados ao Recife pela ferrovia. O trem anunciava um tempo de mudanças, enquanto os chefes políticos locais - senhores de um bando de homens armados - procuravam manter, sob o julgo do latifúndio, as populações urbanas que se desenvolviam com a chegada da estrada de ferro ${ }^{22}$. Os municípios do sul de Pernambuco se configuravam no vetor da expansão do transporte ferroviário e os chefes locais, a exemplo dos paulistas e mineiros da chamada belle époque caipira, conforme denominam Doin ${ }^{23} \mathrm{e}$ demais pesquisadores da $\mathrm{CEMUC}^{24}$, sobre os coronéis do sudeste adotarem posturas e discursos modernos para estabelecer relações "civilizadas" com as instituições e a população urbana em formação ${ }^{25}$. Uma estratégia para preservar os interesses e as práticas de mando tradicionais. 
Um processo que acompanhava a expansão e as novas expressões da vida urbana, mesmo naqueles núcleos rurbanos ${ }^{26}$. Um novo cenário que incluía, também, segmentos sociais neófitos, formados por moradores letrados, profissionais liberais, pequenos comerciantes, prestadores de serviço autônomos e uma gama de pessoas de passagem, migrando de um lugar para outro ao longo dos lugarejos formados pela expansão da ferrovia. Uma constante leva de gente outsider que colocava em alerta a liderança dos estabelecidos ${ }^{27}$. Ou seja, o domínio que exercia o coronel, sobre as rotinas da vida local, enfrentava novos e dinâmicos processos de mudança. Assim, podemos pensar as práticas sociais do coronelismo, tencionadas e muito mais próximas dos desafios da vida urbana, principalmente diante de novos sujeitos, objetos e ritmos que perturbavam o cotidiano tradicional de povoados rurais.

A violência de bandos armados, por sua vez, apresentava-se à disposição da rede de intrigas, tensões e disputas pessoais ou familiares. Tensões que, imbricadas às típicas desavenças por disputa de terras, aproximavam motivações pessoais, políticas e econômicas no rol das práticas violentas típicas do latifúndio. Naquele cenário, o jornal apareceu como "arma onde a luta política, assumia, neles, aspectos terríveis" 28 , publicando matérias que desemborcavam na injúria mais vulgar e veladas promessas de "corrigir", "surrar" ou "por para correr" os desafetos. Alguns chistes contribuíram para gerar ódios e rancores pessoais, servindo para identificar o alcance das representações de honra, vingança e justiça mobilizadas pelos mandões locais, seus parentes e correligionários.

Deste modo, nos jornais pesquisados, vamos verificar que a família Peregrino chamava aquelas terras, Cachoeira Bela; os Marques, Meia Água. Ainda em 1906, rogadas à Justiça e à fragilidade dos cartórios de registro de terra. Uns papéis, muitos carimbos e selos nos despachos, pouco satisfazendo os chefes de cada clã, dispostos a tudo pela manutenção de suas porteiras. Assim, uma década adiante, entre os anos de 1917 e 1919, vamos à leitura de que o conflito descambou para atentados seguidos de vários homicídios. No comando da violência, dois patriarcas experimentados, conhecidos ainda jovens, compadres que ingressaram juntos na Guarda Nacional. Dois homens cismados nos mandos, desmandos e, principalmente, troca de favores. O clientelismo garantia-lhes prestígio e custava-lhes a manutenção das propriedades, o crédito na praça e o plantel de agregados, trabalhadores e cangaceiros. A rede paternalista que irradiavam de si, para também morar na cidade, educar os filhos, procurar frequentar os melhores salões e desenvolver a cordialidade urbana, embora, em seus escritos, apareçam ameaças de vingança e violência confirmadas depois. 


\section{Notas não muito galantes: notícias vindas de Palmares e Maraial}

A violência é compreendida, pelos historiadores, uma das experiências constituintes da história. Ela não deve ser naturalizada ou muito menos colocada enquanto "motor" primário de transformações, sempre fatalmente tingidas pelo sangue derramado. Nos meandros da história, cultura e sociedade, a violência é um fenômeno que se reveste de práticas micro ou macro-históricas, geralmente ligadas, como se afirma, a conflitos relacionados às esferas da vida privada e pública, mobilizados por motivações biológicas ou culturais, como acentua Munchembled ${ }^{29}$.

Tal discurso não é nem da responsabilidade nem da competência do historiador. Quando muito, este pode notar que os séculos passados nos legaram uma dupla concepção de violência, legítima quando implementadas por instituições, como os Estados que decidem a guerra ou como as Igrejas que decretam perseguições contra os "heréticos", ilegítimas se exercidas individualmente contra as leis e contra a moral. Esta ambiguidade fundamental traduz o fato de a violência humana vir ao mesmo tempo do biológico e da cultura.

Pensando nesta perspectiva, a violência praticada pelos clãs Peregrino e Marques, para manejo pelo historiador, requer o bom sentido benjaminiano de que "se imprime na narrativa a marca do narrador, como a mão do oleiro na argila do vaso" ${ }^{30}$, considerando os textos publicados pelos opositores, nas páginas do diário A Província ou do Diario de Pernambuco. Um conjunto de escritos autorais sobre agruras e desafetos, crimes e impunidades. Uma fonte que possibilita verificar as representações da violência levadas a cabo nos grotões canavieiros. E mais ainda, as notas apresentam sutis diferenças entre falar de honra e escrever sobre honra, pois a escrita daqueles patriarcas carrega marcas que, melhor interpretadas, garantem compreensão das tramas que tentavam legitimar emboscadas, tiroteios e assassinatos, associadas à ação política de e na rede de favores onde atuavam.

No conjunto dos escritos impressos, deixados pelos proprietários Peregrino Leite e Antônio Marques, verificamos que tudo começou com uma transação em dinheiro, depois passou à troca de insultos, transformando-se em disputas de terra, emboscadas e crimes de parte a parte. Rixas repassadas de pai para filho, que rogavam vingança, reparo à honra e suscitavam debate público entre facções políticas, sobre a necessidade de pacificar a região canavieira. Um desfecho violento inscrito nos confrontos internos da velha oligarquia pernambucana.

Em 1906, mês de agosto, as querelas "nada galantes" de Maraial apresentavam-se à capital Recife. Daquele distrito enviavam notas agressivas, cheias de ataques à dignidade do opositor. Uma prática bastante comum nos periódicos pernambucanos, usada para desmoralizar desafetos no campo dos negócios, política, literatura e, mesmo, familiar ${ }^{31}$. 
O ataque verbal teve início com uma publicação solicitada pelos cidadãos de Maraial, denominados "Os Assinantes", contra certo "senhor Peregrino Leite, de triste nomeada, muito conhecido neste povoado, em cujas ruas, num só dia, fez entrar três cadáveres, após fato perverso praticado em seu engenho Cobras”. O capitão Peregrino ainda é acusado de "acoitar" toda sorte de criminosos e de realizar cerco ao povoado, tudo porque um de seus "cangaceiros foi desarmado na rua" pela autoridade policial competente. A nota termina, esclarecendo que "Os Assinantes" são cidadãos e que não voltariam a denunciar, em público, as violências e abusos praticados pelo proprietário do engenho Cobras, cujos familiares residiam em Catende, solicitando providências das autoridades municipais em Palmares, para que o capitão Peregrino fosse julgado pelos crimes cometidos.

No mês seguinte, 12 de setembro, Peregrino Leite responde e acusa "Os Assinantes" de serem orquestrados pelo tenente Antônio Marques Soares da Costa e que, entre os signatários estaria, além de poucos homens de posse, um "resto" que seria de "homens desconhecidos da sociedade, tidos em carregadores de frete da estação, vendedores de bichos, cachaceiros, como o é Miguel de Almeida, de andar bebendo no meio da rua". Aqui, Peregrino Leite demonstra a tensão existente entre "civilizados" e "brutos"; entre a postura miliciana dos chamados homens de posse e aqueles submetidos, iletrados, pobres e incivilizados, cabendo aos primeiros resolver suas contendas sem envolver gente “desconhecida, sem eira nem beira". Um típico exemplo da oposição entre estabelecidos e outsiders. Assim, exigia o capitão Peregrino, até com certa habilidade literária, que Antônio Marques apresentasse "as assinaturas dos homens de bem", naquela matéria que mandou publicar e, em seguida, trouxesse à tona "a crônica" de cada um dos "Assinantes", denunciando-lhes as práticas violentas e criminosas que passou a descrever com ironia:

Por que não denunciaram o finado Araújo que assassinou um pobre homem, ao meio dia, no meio da rua? Por que não o prenderam, quando saiu bebendo aguardente em todas as vendas? (...) E Manoel Nunes Viana? Senhor quebrado, dono de uma engenhoca de fogo morto (...) que necessita do auxílio de sua amásia Tereza, tendo por ela desprezado toda família. (...) E Adelino Freire que mandou dar uma surra num mestre de açúcar e tentou dar uma em meu filho, o que não se procedeu porque fui pedir-lhe explicações? Ele - Adelino - deflorou duas moças das quais, uma está na cidade de Palmares. (...) De uma feita, estando a encher, na estação de Maraial, o carro de cana, viu passar um rapaz com uma moça. Chamou o inspetor, o finado Bonfim, combinou em botar o rapaz no tronco, e levar a moça em casa deste. Altas horas juntou-se com o senhor Alfredo Viana e praticaram com a moça uma ação não muito galante. No dia seguinte soltaram o infeliz e (...) chamaram o senhor Juiz que fez o casamento das duas vítimas. Eis a crônica dos Freitas.

O capitão Peregrino ainda descreve outras arbitrariedades provocadas pelos ocultados na epígrafe "Os assinantes", se dizendo em "falência" como muitos agricultores, porém um homem honrado e conhecido de gente importante, que lhe estava destinando 
engenho para administrar em Palmares. O capitão se postava injustiçado e explicava que não houve cerco a Maraial e apenas dispusera, a serviço do delegado, dez homens seus em auxílio à "prisão de Antônio Barroso, irmão de José Sabino, o terror de Maraial”.

O texto de Peregrino Leite procurava demonstrar diversos aspectos: a chamada "crise da lavoura" acompanhada de falências e dívidas contraídas pelos donos de engenho junto a comerciantes e agiotas; a rede de proteção clientelista iniciada na sede do município e distribuída entre os correligionários dos distritos, claramente abandonados pela edilidade pública à sorte dos seus "homens de bem", capazes de atentados e abusos contra a população; as humilhações praticadas por amarrar e surrar desafetos ao tronco, instrumento punitivo da escravidão, porém, ainda imposto como símbolo de poder dos senhores de terra e seus capangas.

A nota destaca ainda, a debilidade da autoridade policial diante das milícias dos proprietários de terra, o que resultava na impunidade e toda sorte de crimes, inclusive racistas, sexuais, financeiros, patrimoniais, etc. Também, em varias matérias saídas no mesmo diário $A$ Província, encontramos relatos das famosas surras levadas por trabalhadores rurais que, apesar de registradas nas delegacias, nunca eram levadas à apuração policial, inclusive prejudicadas porque os donos de terra procuravam não deixar a polícia circular em suas propriedades $^{32}$.

A contenda continuava na edição de 07 de outubro de 1906. Desta vez, aparece o contra-ataque do tenente Antônio Marques da Costa, dirigindo ao chefe político de Palmares, o rosista coronel Leopoldo Marinho Lins, um levantamento da situação de Maraial e as ameaças provocadas por Peregrino Leite. O proprietário do engenho Gigante afirmava que um verdadeiro agricultor "quebra e não mente para enganar, que é falido pela força das circunstâncias", porém, "continuará sempre honrado, digno de toda consideração, ainda que tenha dado prejuízo a terceiros". Continuava, reafirmando seu desafeto por Peregrino Leite, dizendo que não se tratava aquele de um agricultor; mas, um rendeiro velhaco.

O tenente Antônio Marques explicava adiante: "hoje é que a agricultura está em crise, há 12 anos passados, porém ela estava em opulência" e que, no entanto, à época, Peregrino obtinha um crédito e arrendava o engenho Cobras, porém, "no espaço de 4 anos", aquele havia "elevado o débito para 40 ou 50 contos, passando a grande, como grandes foram as surras e mortes que lá houve, sem, no entanto, se preocupar em pagar os empréstimos feitos na praça de Maraial". Assim, Antônio Marques descreve Peregrino Leite um "perdulário rendeiro, que zomba dos credores e fica com todos os bens, sendo inútil recorrer à justiça", por trata-se de "um criminoso impune, protegido por gente que desconhece os fatos". 
As constantes ofensas publicadas em jornal levaram as famílias Marques e Peregrino à rixa pessoal. Nas entrelinhas dos textos de ambos proprietários, fica evidente a dívida de Peregrino Leite contraída junto ao comerciante Antônio Marques que, na situação de momentaneamente "quebrado", perseguia antigo empréstimo feito, tentando arregimentar apoio público dos coronéis de Palmares no interesse de seus negócios. Uma dívida em dinheiro que resultava na captura da propriedade conhecida por Meia Água. Umas terras que, anos depois, são retomadas à força pelos Peregrino, deslocados do vizinho estado das Alagoas. Em 1917, os parentes dos Peregrino controlavam a Prefeitura de Palmares e este fato animou Peregrino Leite, com um bando de cangaceiros, invadir novamente a área em disputa.

Dez anos depois das rixas de 1906, as disputas foram retomadas quando os Marques, reagindo à invasão dos Peregrino, assassinaram a tiros e facadas o jovem de 21 anos, José de Miranda Leite, filho de Peregrino Leite e sobrinho da então esposa do prefeito de Palmares, Dr. Fausto Freire de Carvalho Figueiredo ${ }^{33}$. O prefeito, correligionário do governador Manoel Borba, desconfiava da ligação dos Marques com a oposição chefiada pelo dantista coronel Luiz de França. Um ex-prefeito de Palmares, derrotado na turbulenta eleição municipal de 1915, denunciada como manipulada para fazer o candidato do grupo Marreta ${ }^{34}$, engenheiro e proprietário do Cine Theatro Apollo, derrotar os dantistas e retomar o poder para o antigo grupo liderado pelo coronel Leopoldo Marinho Lins, rosista de maior prestígio e o primeiro prefeito da cidade, eleito em 1893, logo após a emancipação do município. A maior liderança política interessada em manter coesa a unidade territorial do município que incluía os distritos de Maraial, Jaqueira, Catende e Preguiças (Joaquim Nabuco).

O assassinato do jovem José de Miranda Leite desencadeou a onda de crimes que fez de Maraial uma terra sem lei, entregue aos capangas dos clãs Peregrino e Marques. A disputa pela posse da propriedade Meia Água chegou ao clímax, no exato dia de inauguração da iluminação elétrica em Palmares, 20 de maio de 1917. Enquanto toda a região estava convidada pelo prefeito Fausto Figueiredo, inclusive os Marques, para a badalada inauguração, ocorreu na manhã seguinte um tiroteio com mortos e feridos. Este evento resultou nas prisões de Antônio Marques, dois de seus filhos e alguns dos cangaceiros a serviço de seu engenho. Em seguida, a partir dai, aconteceria uma série de intervenções nos tribunais, onde o patriarca dos Marques, valendo-se da influência de um parente ${ }^{35}$ junto ao gabinete do governador Manoel Borba, conseguiu caracterizar legítima defesa "diante de bando invasor constituído por cangaceiros armados pelos Peregrino, procedentes de Alagoas, em amparo da própria vida e dos seus, e que a escaramuça resultou, infelizmente, na morte de 
um dos parentes do capitão". Tal processo foi arquivado e, ao longo de todo o ano de 1918, Peregrino Leite tentou retomá-lo, recebendo expressivo apoio do coronel Fausto Figueiredo.

$\mathrm{O}$ processo foi reaberto, meses depois, condenando os Marques. O fato causou descontentamento, oposição e inquietações em Maraial. No entanto, as eleições municipais e estaduais - começo do segundo semestre de 1919 - conheceram a vitória da situação ${ }^{36}$. Em Palmares, apesar de várias acusações feitas pela oposição dantista, denunciando o doutor engenheiro de ter realizado uma administração municipal "anarquizada e oligarca", conforme carta do coronel Luiz de França, publicada no Diario de Pernambuco, um ano antes, final de 1918. Porém, coincidentemente, um ano depois, ambos mandões dantista e borbista apareceriam mortos ao final de 1919. Dois coronéis, ex-prefeitos de Palmares, assassinados por vingança, sob a acusação de terem acobertado crimes de morte e acoitado criminosos.

\section{Da hecatombe do engenho Gigante à calçada do Lafayette: vingança e impunidade}

A casa grande do engenho Gigante, distrito de Maraial, sofreu um ataque furioso feito pelo bando de cangaceiros a mando de Peregrino Leite, em 15 de fevereiro daquele 1919. A imprensa do Recife chegou a denominar o episódio ousado de "A hecatombe do engenho Gigante". Nele ficou patente a fragilidade e o descompromisso do poder central e das instituições jurídicas e policiais de Pernambuco em procurar conter o ímpeto dos chefes do interior.

$\mathrm{Na}$ medida em que as práticas do mandonismo favoreciam a violência e a impunidade, os coronéis praticavam lances cada vez mais ousados. Tais práticas violentas mediavam a relação das instituições de segurança do estado com os coronéis locais, estes sempre em busca dos figurões da política estadual em troca de apoio para acobertar seus crimes. O jornal A Província, em 16 de fevereiro de 1919, noticiou o ocorrido na casa grande do engenho da família Marques:

\footnotetext{
O engenho Gigante, situado no povoado de Maraial, município de Palmares, de propriedade do senhor Antônio Marques Soares, foi assaltado e tiroteado por um grupo de malfeitores (...) em consequência disso, houve duas mortes, sendo uma do senhor João marques, filho do dono do engenho, e de uma menor que servia como ama na casa daquele senhor (...) consta-se que o assalto foi feito pelo grupo de Peregrino Leite, em represália à morte de seu filho José Peregrino, a mandado da família Marques, fato ocorrido no referido engenho, sítio Cachoeira Bela, em maio de 1917, cujo crime ficou impune até ontem (...)
}

Percebe-se a máxima do olho por olho narrada pela imprensa. Há mais de um ano, entrevistando Peregrino Leite, A Província falava, em um "assassinato bárbaro ainda impune", enquanto a frase final da matéria de fevereiro de 1919 exclamava: "cujo crime ficou 
impune até ontem". A nota completa o desfecho de vingança e a corriqueira existência de muitos incidentes violentos envolvendo famílias e disputas de terra. No caso do engenho Gigante, além da reação à suposta proteção de membros do governo Manoel Borba, obtida por parente dos Marques para livrá-los da cadeia, a matéria demonstra que tais práticas, levadas adiante por questões pessoais e contendas do latifúndio, encontravam-se marcadas pela política beligerante do governo borbista. O jornal denunciava o governador como o grande responsável pelo uso de forças policiais e milicianas, financiadas com recursos do estado e prefeituras, para resguardar interesses eleitorais do grupo político, incentivando atos de violência e perseguições cada vez mais truculentos.

O jornal A Província relata que, durante o ataque ao engenho Gigante, foi assassinado o filho primogênito de Antônio Marques da Costa. O comerciante e senhor de terras João Marques da Costa. Um promissor político e liderança no distrito de Maraial, incentivador de abaixo-assinados pela emancipação política do distrito ${ }^{37}$. Também aparece nos depoimentos e entrevistas feitas pelos parentes, a informação que João Marques da Costa, no ano de 1916, havia declinado ao cargo de subprefeito de Maraial ofertado por Fausto Figueiredo. O fato desagradou o prefeito e colocou em choque os interesses públicos entre os Marques e o grupo situacionista de Palmares. Narra-se que, à época da emboscada e assassinato do filho de Peregrino Leite, o comerciante João Marques da Costa ocupava cargo de delegado de polícia no distrito de Maraial. Um cargo indicado pelo governo do estado e "apoiado por muitos senhores de engenho daquela praça". Por sua vez, os Peregrino apontavam que "essa condição de delegado fez os Marques se armarem para tomar Cachoeira Bela à força, depois de dez anos de relativa tranquilidade entre as famílias".

A cidade de Palmares aparece noticiada, entre 1917 e 1919, em "guerra de coronéis e correligionários". No ano de 1918, uma matéria intitulada "O Pântano Judiciário", edição de 03 de maio do jornal A Província, dava conta dos acontecimentos judiciais em torno do assassinato de outro coronel de nome Siqueira $\mathrm{Neto}^{38}$. A matéria falava da coação do assassino preso na produção de confissão que incriminasse pessoas inocentes. Uma ordem expressa, segundo o denunciante, vinda do próprio governador Manoel Borba, "ao nomear outro juiz para cuidar do caso e toda sorte de calúnias". Meses depois, ocorreria o assassinato do coronel Luiz de França, e mais uma carta de Palmares seria publicada, na edição de 07 de novembro de 1919, intitulada "A onda de sangue", atribuída ao borbismo e seus correligionários: 
uma hora após o crime, mas nada sofrerão. O governador Manoel Borba não há de quebrar sua linha da conduta, só porque o assassinado é o senhor coronel Luiz de França, chefe dantista de Palmares e membro do Diretório Democrático (...). Quem será a vítima de amanhã? Só o senhor Borba, ou os seus agentes da morte, o podem saber. Enquanto ele for governador, enquanto estiver ali, no poder, na Praça da República, a maré de sangue pernambucano não baixará.

A nota assinada pelos dantistas de Palmares profetizava o crime da calçada do Café Lafayette. Poucos dias depois, 17 de dezembro de 1919, seguia-se aquele roteiro de homicídios. O senador Fausto Freire de Carvalho Figueiredo, 51 anos, ex-prefeito de Palmares, era assassinado. O criminoso um proprietário de terra de 75 anos idade. O patriarca Antônio Marques Soares da Costa que, ainda no local do crime, afirmava aos jornais: "matei o Dr. Fausto Figueiredo porque ele mandou assassinar meu filho. Sou um patriota! Salvei Palmares das garras daquele homem. Tenho o anjo Santo Miguel do meu lado. Estou convencido, sou um patriota!". Logo depois, apontava outras motivações para o crime: "recebi um convite do então prefeito Fausto Figueiredo, em 20 de maio de 1917, para inauguração da luz elétrica de Palmares". O convite, julgava, carregava o objetivo de afastá-lo do distrito, exatamente no dia da invasão de suas terras pelo bando de Peregrino Leite. Depois, citava a "mofina" contra ele publicada no Diario de Pernambuco, falando que o chefe político de Palmares era o subscritor, responsável por grande calúnias e que não havia esclarecido a verdade dos fatos sobre a morte do filho de Peregrino Leite.

Nos dias que se seguiram ao crime de grande repercussão nos meios políticos, a imprensa publicava algumas notas em defesa do finado ex-prefeito. Muitos correligionários, religiosos, bacharéis e senhores de terra de Palmares manifestavam apoio à família enlutada e refutavam que o senador houvesse, alguma vez, perseguido os Marques. Também, foi entrevistado Abel Soares da Costa, filho do assassino, que relatava a sucessão de acontecimentos que levaram à "loucura" seu velho pai, depois de tanto sofrimento e perseguições:

O engenho Gigante fica a seis léguas de Palmares. Desde trinta anos vivia ali meu pai para sustento da nossa numerosa família. (...) O senhor Peregrino Leite vinha manifestando o interesse de se apoderar do engenho. (...) Politicamente, nunca procurávamos estar em evidência, mas, em 1915, em função da eleição do Dr. Fausto Figueiredo, ficamos do lado dele, o que causou mesmo certo ressentimentos do Coronel Luiz de França, chefe dantista de Palmares. (...) Nunca almejamos cargos de destaque, mas um ano depois o prefeito Fausto Figueiredo ofereceu a meu irmão João Marques, abastado comerciante de Maraial, a direção do distrito, este recusou, o que desgostou o chefe situacionista. (...) Dias depois, o bando de Peregrino Leite invadiu nossa propriedade, plantando nela, como se o sítio the pertencesse. (...) Travou-se luta, resultando na morte do filho de Peregrino. (.... ) Tivemos ordem de prisão. Meu pai, eu e 16 trabalhadores ficamos 21 dias não prisão. (...) Instaurado o processo sofremos rude perseguição, a ponto do governador do estado exonerar o então delegado Nicolau Pinto Teixeira, que dias depois voltou ao cargo por exigências do Dr. Fausto. Porém, a razão da nossa causa, está no fato 
do Tribunal de Justiça ter colocado abaixo o processo que nos era movido.(...) No dia 14 de fevereiro deste ano, quando faltava poucos dias para decisão do Tribunal, Peregrino e seu bando invadiu nossa propriedade e assassinou meu irmão João Marques (...) Minha tia de 76 anos e uma criança de 7 anos. (....) Dias depois abriuse um inquérito que não foi a diante e assim ficaram impunes os responsáveis por esses crimes hediondos.

No longo depoimento é possível identificar as práticas mandonistas e sua principal face de poder, o coronelismo. Aparece a denúncia da rede clientelista que permeava a relação entre os vários extratos de proprietários rurais, submetidos à rede de dependência que a conjuntura da política estadual oferecia naquele momento. A interrupção ou ausência dessa "troca proveitosa" de favores e proteção poderia resultar em punição por parte da Justiça. Assim, a morte por vingança tinha por objetivo reparar os crimes sofridos, muitos cometidos em nome da honra, revide violento, uso de bandos armados ou o recurso ao expediente da tocaia. $\mathrm{O}$ aniquilamento do adversário, geralmente detentor de algum prestígio, cargo político ou padrinho graúdo capaz de acobertar crimes e oferecer impunidade. Uma moeda de troca que não intimidava e fazia prosperar novos crimes. Um status quo que a política oligarquia perpetrava para manter seus interesses.

Os assassinatos dos coronéis Siqueira Neto, Luiz de França e Fausto Figueiredo seguiram essa lógica de vingança, enquanto o contexto de violências recrudescidas, ao final do governo Manoel Borba, suscitava uma característica comum: os assassinos alegavam crime de vingança, sem registrar rixa pessoal, bate-boca existente ou ódio que revelasse, publicamente, culpa pelos atentados e homicídios. Há na chamada "onda de sangue" de Palmares, a insinuação de que os coronéis mandavam matar, felicitavam a morte ou protegiam os assassinos. Fato que demonstrava o intricado jogo de mando pessoal dos coronéis. Ou melhor, as críticas e acusações feitas ao governador Manoel Borba, pelos que cobravam justiça contra aquela "onda de sangue", são as mesmas sofridas pelos mandões locais. Os homicídios praticados, nos inquéritos policiais, apontavam a incitação e o acobertamento de crimes pelos coronéis, procurando favorecer seus apadrinhados.

\section{Considerações finais}

Procurar história esquecida em jornais antigos, levou ao episódio da calçada do Café Lafayette, Recife, dezembro de 1919. O assassinato de um senador estadual, meses depois de assumir a vice-presidência da Assembleia Legislativa de Pernambuco e gozar da condição de liderança maior da cidade de Palmares. O cenário que encorajou um assassino de 75 anos, agricultor no rústico distrito de Maraial, cometer tal homicídio. Acontecimento que, para ser 
explicado, exige retroceder a leitura em jornais do Recife, até identificar a primeira menção feita aos principais envolvidos nas contendas entre as famílias Peregrino e Marques. A disputa de terras que terminou envolvendo questões políticas e eleitorais da época do governo Manoel Borba. O fato curioso foi o repertório mobilizado nos textos difamatórios publicados de parte a parte, onde o uso de ideias de modernidade aparecem cobrando posturas mais condizentes, morais e civilizadas às autoridades municipais e estaduais, exigindo a aplicação da lei ou, ao contrário, ameaçando tomar aquelas "providências", em defesa da honra e em retaliação ao descaso das autoridades.

Tais "providencias" em torno de disputa de terras, contras as mofinas publicadas nos jornais, crimes e impunidade, apadrinhamentos e trocas de favores, são todas próprias do mandonismo. Um conjunto de práticas da política tradicional, mobilizado pelos coronéis para lidar com as transformações ocorridas ao longo das primeiras décadas do século passado. Acrescente-se, igualmente, um lugar de representações aludidas à "modernidade sem mudança". Aquele processo que levou a oligarquia rural a lidar com o avanço das relações capitalistas, crescente urbanização, transporte ferroviário, usinas de açúcar, novos costumes e modas urbanas, sem alterar, no entanto, as relações consagradas do latifúndio. Relações de subordinação que sustentavam a tradição de mando local, enquanto se esperava "civilizar por cima" e controlar as "novidades" ditas modernas. Ou melhor, estratégias adotadas para não diminuir ou arriscar privilégios, posses e autoridade.

Aliás, o que explica a sucessão de crimes de vingança em Palmares e seus distritos, ao longo de 1917 a 1919, resultando em várias pessoas feridas ou assassinadas (incluindo crianças, jovens, idosos e mulheres), é o uso da violência como recurso político, contra um pano de fundo meramente retórico e legalista. Por isso, toda sorte de delitos foram identificados: crimes levados a cabo pelos coronéis, parentes, agregados ou membros de sua clientela. Delitos patrimoniais, financeiros, racistas, sexuais, etc. Um conjunto de crimes enredado pela impunidade, meramente denunciada pelas cúpulas políticas, porém grassadas nas relações promíscuas entre os poderes do estado oligárquico, incentivadores do apadrinhamento e da impunidade. Um capítulo local onde o mandonismo se revelava capilar, diluído nas resistências da oligarquia canavieira, ao tempo que buscava realimentar o poder a partir das práticas do coronelismo, regido sob o manto da civilidade e daquele discurso que falava sobre progresso e civilização.

Assim, depois de grande comoção pública, o desfecho do crime da calçada do badalado Café Lafayette, colocava ponto final às querelas iniciadas em 1906. Também, ao longo de 1920, enviou-se algumas notas à imprensa recifense, exaltando a memória do 
moderno empreendedor coronel Fausto Figueiredo. Em 1923, o patriarca septuagenário Antônio Marques aparece absorvido por júri popular e, meses depois, publicou-se a notícia de seu falecimento, sem que a família continuasse no ramo da lavoura. Os Peregrino mudariam novamente para o estado vizinho de Alagoas, desaparecendo das querelas futuras envolvendo Cadente e Maraial. Os dois antigos distritos de Palmares foram transformados em cidades autônomas, no ano de 1928. As mortes violentas dos opositores, coronel Luiz Amaro de França, dantista; e do coronel Fausto Figueiredo, borbista, fez a cidade de Palmares perder, por algum tempo, representação política mais expressiva. Um status logo retomado às ordens de outros clãs de proprietários rurais. Enfim, um capítulo da história de Pernambuco inserido nas disputas intra-oligarquicas da primeira fase da República brasileira.

\section{Notas}

\footnotetext{
${ }^{1}$ Periódico ligado ao Partido Liberal, A Província circulou entre os anos de 1872 a 1933. A Biblioteca Nacional disponibiliza seu acervo digitalizado, no sítio: http://bndigital.bn.gov.br/hemeroteca-digital.

${ }^{2}$ Mesorregião denominada Zona da Mata Sul de Pernambuco. Na atualidade, as cidades de Palmares, Catende e Maraial são municípios autônomos.

${ }^{3}$ Engenho Gigante em Maraial, pertencente aos Marques, acusados pelos Peregrino de se apossarem de faixa de terra do Engenho Cachoeira Bela ou Meia Água.

${ }^{4}$ Conflito envolvendo as famílias Jardim, Miranda e Ivo de Garanhuns, ocorrido em 15 de janeiro de 1917, resultando em 18 pessoas mortas. O trabalho de Mário Márcio de A. Santos, "Anatomia de uma tragédia: a Hecatombe de Garanhuns", editado em 1992 pelo Arquivo Público Estadual de Pernambuco, apresenta as motivações políticas, eleitorais e pessoais envolvendo o episódio.

${ }^{5}$ BURSZTYN, Marcel. $O$ Poder dos donos. Planejamento e clientelismo no Nordeste. Rio de Janeiro: Vozes, 1985, p. 20.

${ }^{6}$ LEAL, Victor Nunes. Coronelismo, Enxada e Voto. Rio de Janeiro: Forense, 1948.

${ }^{7}$ CARVALHO, José Murilo de. Mandonismo, Coronelismo, Clientelismo: Uma Discussão Conceitual. DADOS - Revista de Ciências Sociais, vol. 40, nº 3, p. 229-250.

${ }^{8}$ A chamada "Hecatombe de Vitória de Santo Antão" ocorreu em 27 de junho de 1880, envolvendo facções locais do Partido Liberal. Os "Democratas" e os "Leões", como eram conhecidos, entraram em choque na praça da Igreja Nossa Senhora do Rosário dos Pretos, em Vitória. Os conflitos se estenderam até Recife, resultando em 16 mortos e muitos de feridos.

${ }^{9}$ HOFFNAGUEL, Marc Jay. O Partido Liberal de Pernambuco e a Questão Abolicionista (1880-88). CLIO Revista de Pesquisa Histórica - n ${ }^{\circ} 23,2005$, p. 9.

${ }^{10}$ ABREU, Alzira Alves de. A Sucessão Pernambucana de 1911. Dicionário Histórico Biográfico da Primeira República (Recurso eletrônico), FGV, 2015.

${ }^{11}$ CARVALHO, J.M. op. cit., p. 247.

${ }^{12}$ GOMES, Ângela de Castro e FERREIRA, Marieta Moraes. Primeira República: um balanço historiográfico. Estudos Históricos, Rio de Janeiro, vol. 2, nº 4, 1989, p. 251.

${ }^{13}$ DOLHNIKOFF, Miriam. O pacto imperial: origens do federalismo no Brasil do século XIX. São Paulo: Globo, 2005.

${ }^{14}$ CONNIFF, M. L. Política a no Brasil: a ascensão do populismo 1925-1945. Rio de Janeiro: Relume Dumará, 2006.

${ }^{15}$ CARVALHO, J.M. op. cit., p. 239.

${ }^{16}$ ALONSO, Ângela. Ideias em movimento - A Geração de 1870 na crise do Brasil-Império. Rio de Janeiro, Paz e Terra, 2002.

${ }_{17}$ OLIVEN, RG. Urbanização e mudança social no Brasil. Rio de Janeiro: Centro Edelstein, 2010.

${ }^{18}$ PORTO, José da Costa. Os tempos de Dantas Barreto. Recife. Editora Universitária, 1974, p. 138.

${ }^{19}$ PÉCAUT, Daniel. Os intelectuais e a política no Brasil: entre o povo e a nação. São Paulo: Ática, 1998.
} 
${ }^{20}$ Desde o Congresso Agrícola do Recife, realizado em 1878, o debate em torno de uma crise da lavoura canavieira tornou-se parte integrante do discurso político, técnico e moral envolvendo engenhos, usinas, mão de obra, subsídios, modernização do setor, etc., apresentando-se, desde então, um tema recorrente na imprensa periodista de Pernambuco.

21 "A cidade do clube de letras foi representada ufanamente como um importante núcleo comercial e agrícola. No entanto, se encontrava restringida pelas relações tradicionais e oligárquicas", cf. CARVALHO, Vilmar Carvalho. Letrados e Ufanos: história do Club Litterario de Palmares (1882-1910). Recife: Edições Bagaço, 2011 , p. 17.

${ }^{22}$ A ferrovia atingiu a região de Palmares, Pernambuco, no ano de 1862.

23 DOIN, J.E. de Mello; PERINELli N, H.; PAZIANI, R.R.;PACANO, F.A. A belle Époque caipira: problematizações e oportunidade interpretativas da modernidade e urbanização do mundo do café (1850-1930). Revista Brasileira de História: São Paulo: 2007. Vol. 27, no. 53.

${ }^{24}$ Centro de Estudos da Modernidade e Urbanização do Mundo do Café. CEMUMC/UNESP.

${ }^{25}$ SEVCENKO, Nicolau (org). História da vida privada no Brasil República: da Belle Époque à Era do Rádio. São Paulo: Companhia das Letras, 1998.

${ }^{26}$ FREYRE, Gilberto. Rurbanização: Que é?. Recife: Massangana, 1982.

${ }^{27}$ ELIAS, Norbert; SCOTSON, John L. Os estabelecidos e os outsiders: sociologia das relações de poder a partir de uma pequena comunidade. Rio de Janeiro: Jorge Zahar Editor, 2000.

28 SODRÉ, Nelson Werneck. História da Imprensa no Brasil. São Paulo: Mauad, 1994. p. 324

${ }^{29}$ MUCHEMBLED, Robert. História da violência: do fim da Idade Média aos nossos dias. Rio de Janeiro: Forense Universitária, 2012.

${ }^{30}$ BENJAMIN, Walter. Magia e técnica, arte e política, 3. ed., São Paulo: Brasiliense, 1987.

31 NASCIMENTO, Luis do. História da imprensa de Pernambuco (1821-1954) Volume I. Diário de Pernambuco. $2^{\text {a }}$ Edição. Imprensa Universitária. Universidade Federal de Pernambuco. Recife. 1968.

32 Semanas antes do incidente do ataque ao Engenho Gigante, nota enviada à redação do jornal A Província, edição $\mathrm{n}^{\circ}$ 02, de 03 de janeiro de 1917, dá conta de violenta surra aplicada em trabalhador, socorrido para hospital em Palmares: " não podendo caminhar, veio numa rede e se acha em estado grave", diz a nota intitulada "Uma denúncia".

${ }^{33}$ Fausto Freire de Carvalho Figueiredo (1868-1919), além de membro do Clube Literário de Palmares, foi um dos editores do Jornal O Progresso, que circulou no município entre 1897 e 1900, onde assinou a coluna "De Bicicleta", dedicada à divulgação de temas sobre costumes modernos, também o idealizador e proprietário do Cine Theatro Apollo, inaugurado em 1914, em conjunto com os sócios Otaviano Lago e Arthur Magalhães.

${ }^{34}$ Denominação dos rosistas, derivada da alcunha "Chico Marreta" atribuída, pelos adversários, ao Conselheiro Rosa e Silva. Em Palmares e região, o grupo marreta era liderado pelo Coronel Leopoldo Marinho Lins.

${ }^{35}$ Uma nota enviada de Recife, publicada no A Província, ed. 149, de 02 de julho de 1917, relata: " O Sr. Antonio Marques diz-se parente próximo do capitão ajudante de ordens do senhor governador e por isso se julga imune de qualquer punibilidade".

${ }^{36}$ Fausto Figueiredo elegeu seu sucessor, Dr. Virgínio Freire Barbosa da Silva e, também, elegeu-se senador estadual pelo PRD, apoiando o candidato a governador José Rufino Bezerra Cavalcanti, apresentado por Manoel Borba. Fausto Freire expõem os motivos desses apoios em carta enviada para o Diario de Pernambuco, em 01 de agosto de 1919.

37 No ano de 1913, membros das famílias Marques e Peregrino chegam a subscrever abaixo-assinado pela emancipação de Catende, cf. Diario de Pernambuco, edição no 105, 20 de abril de 1913.

${ }^{38}$ Proprietário rural e gerente da Usina Catende, assassinado na Estação de Palmares, por ex-empregado que havia recebido uma surra em seu engenho. Varias matérias no Diario de Pernambuco, no mês junho de 1918, dão conta de envolvimento de outros coronéis, acusados de incentivar esse assassinato.

\section{Referências Bibliográficas}

ABREU, Alzira Alves de. A Sucessão Pernambucana de 1911. Dicionário Histórico Biográfico da Primeira República (Recurso eletrônico), FGV, 2015.

ALONSO, Ângela. Ideias em movimento - A Geração de 1870 na crise do Brasil -Império. Rio de Janeiro, Paz e Terra, 2002.

ANDRADE, Manoel Correia. Do banguê à usina. In: Espaço e Tempo na agroindústria canavieira de Pernambuco. Estudos Avançados, 2011, p. 271-272.

BENJAMIN, Walter. Magia e técnica, arte e política, 3. ed., São Paulo: Brasiliense, 1987. 
BURSZTYN, Marcel. O Poder dos donos. Planejamento e clientelismo no Nordeste. Rio de Janeiro: Vozes, 1985.

CARVALHO, José Murilo de. Mandonismo, Coronelismo, Clientelismo: Uma Discussão Conceitual. DADOS - Revista de Ciências Sociais, vol. 40, n 3, 1996, p. 229-250.

CARVALHO, Vilmar Carvalho. Letrados e Ufanos: história do Club Litterario de Palmares (1882-1910). Recife: Edições Bagaço, 2011.

CONNIFF, M. L. Política a no Brasil: a ascensão do populismo 1925-1945. Rio de Janeiro: Relume Dumará, 2006.

DOIN, J.E. de Mello; PERINELLI N, H.; PAZIANI, R.R.; PACANO, F.A. A belle Époque caipira: problematizações e oportunidade interpretativas da modernidade e urbanização do mundo do café (1850-1930). Revista Brasileira de História: São Paulo: 2007. Vol. 27, nº 53.

DOLHNIKOFF, Miriam. O pacto imperial: origens do federalismo no Brasil do século XIX. São Paulo: Globo, 2005.

ELIAS, Norbert; SCOTSON, John L. Os estabelecidos e os outsiders: sociologia das relações de poder a partir de uma pequena comunidade. Rio de Janeiro: Jorge Zahar Editor, 2000.

FREYRE, Gilberto. Rurbanização: Que é?. Recife: Massangana, 1982.

GOMES, Ângela de Castro e FERREIRA, Marieta Moraes. Primeira República: um balanço historiográfico. Estudos Históricos, Rio de Janeiro, vol. 2, nº 4, 1989, p. 251.

HOFFNAGUEL, Marc Jay. O Partido Liberal de Pernambuco e a Questão Abolicionista (1880-88). CLIO - Revista de Pesquisa Histórica - nº 23, 2005, p. 9.

LEAL, Victor Nunes. Coronelismo, Enxada e Voto. Rio de Janeiro: Forense, 1948.

MUCHEMBLED, Robert. História da violência: do fim da Idade Média aos nossos dias. Rio de Janeiro: Forense Universitária, 2012.

NASCIMENTO, Luis do. História da imprensa de Pernambuco (1821-1954) Volume I. Diário de Pernambuco. $2^{\mathrm{a}}$ Edição. Imprensa Universitária. Universidade Federal de Pernambuco. Recife. 1968.

OLIVEN, RG. Urbanização e mudança social no Brasil. Rio de Janeiro: Centro Edelstein, 2010.

PÉCAUT, Daniel. Os intelectuais e a política no Brasil: entre o povo e a nação. São Paulo: Ática, 1998.

PORTO, José da Costa. Os tempos de Dantas Barreto. Recife. Editora Universitária, 1974.

SANTOS, Mário Márcio de A. Anatomia de uma tragédia: a Hecatombe de Garanhuns. Recife: Arquivo Público Estadual de Pernambuco, 1992.

SEVCENKO, Nicolau (org). História da vida privada no Brasil República: da Belle Époque à Era do Rádio. São Paulo: Companhia das Letras, 1998.

SODRÉ, Nelson Werneck. História da Imprensa no Brasil. São Paulo: Mauad, 1994

\section{Fontes e Documentos}

Os Assinantes. Nota de Maraial, 1906. Jornal A Província, ed. 164, de 21 de julho de 1906. Hemeroteca da Biblioteca Nacional. Disponível em < memória.bn.br>. Acesso em 28 de junho de 2017.

Peregrino Leite. Nota de Maraial, 1906. Jornal A Província, ed. 174, de 02 de agosto de 1906. Hemeroteca da Biblioteca Nacional. Disponível em < memória.bn.br $>$. Acesso em 28 de junho de 2017. 
Os mesmos Assinantes. Nota de Maraial, 1906. Jornal A Província, ed. 197, de 25 de agosto de 1906. Hemeroteca da Biblioteca Nacional. Disponível em < memória.bn.br >. Acesso em 28 de junho de 2017.

Peregrino Leite. Nota de Maraial, 1906. Jornal A Província, ed. 206, de 12 de setembro de 1906. Hemeroteca da Biblioteca Nacional. Disponível em < memória.bn.br>. Acesso em 28 de junho de 2017.

Manoel Nunes Viana. Nota de Maraial, 1906. Jornal A Província, ed. 226, de 22 de setembro de 1906. Hemeroteca da Biblioteca Nacional. Disponível em < memória.bn.br>. Acesso em 30 de junho de 2017.

Peregrino Leite. Nota de Maraial, 1906. Jornal A Província, ed. 226, de 05 de outubro de 1906. Hemeroteca da Biblioteca Nacional. Disponível em < memória.bn.br>. Acesso em 30 de junho de 2017.

Antonio Marques Soares da Costa. Nota de Maraial, 1906. Jornal A Província, ed. 228, de 07 de outubro de 1906. Hemeroteca da Biblioteca Nacional. Disponível em < memória.bn.br>. Acesso em 30 de junho de 2017.

Denúncia. Surra em trabalhador do Engenho Gigante, 1917. Jornal A Província, ed. 002, de 03 de janeiro de 1917. Hemeroteca da Biblioteca Nacional. Disponível em < memória.bn.br>. Acesso em 10 de julho de 2017.

H. Mommaram (Pseudônimo). "Apreciando" (cita violência e impunidade em Maraial), 1917. Jornal A Província, ed. 149, de 22 de julho de 1917. Hemeroteca da Biblioteca Nacional. Disponível em < memória.bn.br>. Acesso em 10 de julho de 2017.

Ainda um assassinato bárbaro impune, 1917. Jornal A Província, ed. 355, de 25 de dezembro de 1917. Hemeroteca da Biblioteca Nacional. Disponível em < memória.bn.br>. Acesso em 10 de julho de 2017.

Assassinato do Coronel Siqueira Netto. Nota de Palmares, 1918. Jornal A Província, ed. 119, de 03 de maio de 1918. Hemeroteca da Biblioteca Nacional. Disponível em < memória.bn.br>. Acesso em 20 de julho de 2017.

O Pântano de sangue. Nota de Palmares, 1918. Jornal A Província, ed. 154, de 07 de julho de 1918. Hemeroteca da Biblioteca Nacional. Disponível em < memória.bn.br>. Acesso em 20 de julho de 2017.

O Engenho Gigante foi assaltado e tiroteado, 1919. Jornal A Província, ed. 106, de 16 de fevereiro de 1919. Hemeroteca da Biblioteca Nacional. Disponível em < memória.bn.br>. Acesso em 20 de julho de 2017.

Engenho Gigante à venda, 1919. Jornal A Província, ed. 142, de 27 de maio de 1919. Hemeroteca da Biblioteca Nacional. Disponível em < memória.bn.br>. Acesso em 20 de julho de 2017.

Um covarde atentado ao Coronel Luis de França, 1919. Jornal A Província, ed. 302, de 06 de novembro de 1919. Hemeroteca da Biblioteca Nacional. Disponível em < memória.bn.br>. Acesso em 20 de julho de 2017.

A onda de sangue. Nota de Palmares, 1919. Jornal A Província, ed. 303, de 07 de novembro de 1919. Hemeroteca da Biblioteca Nacional. Disponível em < memória.bn.br >. Acesso em 20 de julho de 2017.

O Assassinato do Dr. Fausto Figueiredo, 1919. Jornal A Província, ed. 345, de 19 de dezembro de 1919. Hemeroteca da Biblioteca Nacional. Disponível em < memória.bn.br>. Acesso em 25 de julho de 2017.

Depoimento de Abel Soares da Costa, sobre o pai Antônio Marques Soares da Costa. Entrevista, 1919. Jornal A Província, ed. 346, de 20 de dezembro de 1919. Hemeroteca da Biblioteca Nacional. Disponível em < memória.bn.br>. Acesso em 25 de julho de 2017. 